III Russian National Conference

"Information Technology in Biodiversity Research"

\title{
Weed activity in arable plant communities in the Central Urals (Sverdlovsk oblast)
}

\author{
Pavel V. Kondratkov*(a), Alyona S. Tretyakova (b) \\ (a) ORCID: 0000-0001-6472-5455, \\ Ural Federal University, 19 Mira Street, 620003 Ekaterinburg, Russia \\ (b) ORCID: 0000-0001-8735-4482, \\ Ural Federal University, 19 Mira Street, 620003 Ekaterinburg, Russia, \\ Russian Academy of Sciences, Ural Branch: Institute Botanic Garden, \\ 202a, 8 Marta Street, 620144 Ekaterinburg, Russia
}

\begin{abstract}
Weed activity is an integral criterion based on the abundance and frequency of weeds occurrence in crops. Identifying the aggressive, underactive and nonactive weed species is essential for effective agriculture management. In arable plant communities of the Central Urals there are four activity groups of weeds. The group of the most active (aggressive) weeds includes 40 species or $16 \%$ of weed species present in the Central Urals. Within this group, weeds most common in crops form a group of highly active species with a high abundance (7\% of the total weed species composition). The remaining $9 \%$ comprise a group of moderately active weeds which can also be considered as the most adapted to arable plant communities. Underactive and nonactive weeds make up most of the area's weed species composition (84\%). Underactive weeds (82 species or 32\%) were found in arable plant communities of many crops, but mainly in small numbers. The group of nonactive weeds was the most diverse and included about half of the weed species present in the Central Urals $(52 \%)$.
\end{abstract}

Keywords: alien species, arable plant communities, cereal, crops, root crop, weeds

(C) 2020 Pavel V. Kondratkov, Alyona S. Tretyakova

This is an open access article distributed under the terms of the Creative Commons Attribution License (CC BY 4.0), which permits unrestricted use, distribution, and reproduction in any medium, provided the original author and source are credited.

Published by Ural Federal University and peer-reviewed under responsibility of BDI-2020

(III Russian National Conference "Information Technology in Biodiversity Research")

\section{Introduction}

In Russia there is a large number of long-term studies of weed species composition (in the northwest and middle zone of the European part of Russia (Mirkin et al. 1985; Ulyanova 1985; Terekhina 2000; Ulyanova 2005; Khasanova et al. 2014; Palkina 2015; Tuganayev et al. 2015; Khasanova et al. 2016; Tretyakova and Kondratkov 2018a, 2018b; Kondratkov and Tretyakova 2019a, 2019b). It was shown that the regional weed species diversity varies from 200 to 350 species and the level of weed species richness was positively related to the area under crops (Tretyakova et al. 2020).

\footnotetext{
* Corresponding author. E-mail address: pavel.kondratkov@urfu.ru
} 
We suggest that the study of weed species composition should be amplify by their activity in arable land by which we mean the selection a group of aggressive and competitive weeds, random weeds, and a transitional group in which weeds can change their status under various circumstances. Unfortunately there are no generally accepted classifications of weeds by activity in arable land as well as there are no fixed terms for the weed groups, however, some researchers distinguish different groups of weeds calling them noxious weeds, aggressive, competitive, obligate or facultative, economically significant or not significant (e.g. Holzner 1982; Gbèhounou 2013; Galon et al. 2015; Palkina 2015; Rana and Rana 2016).

The assessment of weed activity will allow to develop a phytosanitary zoning scheme of Sverdlovsk oblast. It is necessary for predicting the weed contamination of crops and developing the protective measures. All this will contribute to the optimization of regional farming systems.

\section{Materials and methods}

The study was carried out in Sverdlovsk oblast, the Central Urals. The area of the region is 194.8 thousand $\mathrm{km}^{2}$; its length from north to south is $660 \mathrm{~km}$ and from west to east is $560 \mathrm{~km}$. The northern border of Russian agriculture passes through the region; therefore, the arable areas are located mainly in the southeastern and south western parts of the region (the southern taiga and northern forest-steppe). The extreme northern areas under crops are in Alapaevsk district (the middle taiga). In the southern part of the region gray forest soils are prevalent, and in the extreme southwest and southeast there are leached and podzolized chernozems and meadow-chernozem soils.

The climate of the studied area is continental. The annual amount of precipitation decreases from north $(450-650 \mathrm{~mm})$ to south $(350-320 \mathrm{~mm})$. The average temperature in July (the warmest month) is $+18^{\circ} \mathrm{C}$. The average temperature in January (the coldest month) is $-16^{\circ} \mathrm{C}$. The duration of the snow cover lasts $150-160$ days in the western and southern parts and 170-180 days in the northern part. The thickness of the snow cover is up to $70 \mathrm{~cm}$. The duration of the growing season varies from 160-170 days in the west and south and 110-120 days in the northern part. Late spring and early autumn frosts are common, which markedly shorten the frost-free period. The positive temperatures sum varies from $1800^{\circ} \mathrm{C}$ (in the north) to $2300^{\circ} \mathrm{C}$ (in the south). The hydrothermal coefficient varies along here from $0.85-1.8$.

According to the Russian Federal State Statistics Service, the areas under crops in Sverdlovsk oblast reached 835.9 thousand ha, which is $4.3 \%$ of the total region area. Among agriculture forage crops (51.4\%), grain and leguminous crops (39.5\%) are most prevalent. The proportion of industrial crops and open ground vegetables is $2.5 \%$ and $6.6 \%$ respectively.

The study of the weed species composition was carried out in 2015-2019 by the method of route counts (Baranova 2002; Scherbakov and Maiorov 2006) in all the arable areas in the region. One route covered one cultivated crops field and came to no less than $400 \mathrm{~m}$ per each field. The study of weed communities of industrial, row crops and perennial grasses began with the stage of stemming and branching, for grain crops began with the stage of tillering and ended before harvesting. For perennial grasses the 1 st year planting were examined. For biennial row-crop and winter crops both 1st and $2 \mathrm{~d}$ year plantings were examined. The peculiarities of agrotechnical methods, as well as the use of fertilizers, were not taken into account. Weeds referred to any plants in crops that did not serve the crop purpose including other cultivated plants. Weeds were taken 
into account in any age state (seedlings, juvenile, immature, generative, excluding seeds), in any phenological state (vegetation, budding, flowering, fruiting) and in any vital state (normally developed and depressed). The crops of spring cereals, industrial and forage crops (oats, wheat, barley, corn, sunflower, flax, rapeseed, white mustard), winter crops (rye, wheat), row crops (potatoes, carrots, beets, cabbage, radish, turnip), and perennial grasses (crops of clover and alfalfa) were investigated. A total of 120 fields were examined.

The weed activity in arable plant communities was determined based on the abundance and frequency of their occurrence. The abundance was determined by A.I. Maltsev's eye scale (1962) from score 1 (low infestation degree) to score 4 (high infestation degree). The frequency of occurrence was determined by (1) the number of crops in which the weed species was found and (2) the constancy class: IV class (high occurrence), in which the weed species occurs in $61-100 \%$ of the surveyed arable plant communities; III (moderate occurrence), in which the species occurs in 41-60\% of surveyed communities; II (low occurrence), in which the species occurs in $21-40 \%$ of surveyed communities; and I (very low occurrence), in which the species occurs in less than $20 \%$ of surveyed communities (Markov 1972; Palkina 2015). Four activity groups of weeds were identified (Table 1).

Table 1. Weed activity criteria.

\begin{tabular}{|l|c|c|l|}
\hline \multirow{2}{*}{ Activity groups } & \multirow{2}{*}{ Abundance } & \multicolumn{2}{|c|}{ Frequency of occurrence } \\
\cline { 3 - 4 } & & $\begin{array}{c}\text { Constancy } \\
\text { class }\end{array}$ & \multicolumn{1}{|c|}{ Occurrence in arable plant communities } \\
\hline Highly active & $3-2$ & IV & $\begin{array}{l}\text { high occurrence, registered in arable plant } \\
\text { communities of all the examined crops }\end{array}$ \\
\hline $\begin{array}{l}\text { Moderately } \\
\text { active }\end{array}$ & 2 & III & $\begin{array}{l}\text { moderate occurrence, registered in most arable } \\
\text { plant communities of the examined crops or, } \\
\text { less often, all the crops }\end{array}$ \\
\hline Underactive & $2-1$ & II & $\begin{array}{l}\text { low occurrence, registered in arable plant } \\
\text { communities of half of the examined crops }\end{array}$ \\
\hline Nonactive & 1 & I & $\begin{array}{l}\text { very low occurrence, registered in arable plant } \\
\text { communities of a single examined crop }\end{array}$ \\
\hline
\end{tabular}

\section{Results and discussion}

The weed species composition in the Central Urals included 258 vascular plant species belonging to 165 genera and 41 families. The most species-rich families were Asteraceae, Poaceae, Brassicaceae, Caryophyllaceae, and Fabaceae. The most speciesrich genera were Vicia and Potentilla (which included 7 species each), Trifolium (6 species), Persicaria and Rumex (5 species each), and Artemisia, Brassica, Medicago, Poa, Ranunculus, and Galium (4 species each). Monocarpic (50.8\% or 131 species) and polycarpic (49.2\% or 127 species) herbaceous plants were in equal proportions in the life forms spectrum. In the weed flora most monocarpic plants were represented by annual grasses. More than half of polycarpic species (52\%) were plants with intensive vegetative propagation, including species with long and short rhizome, stolon-forming, rootsucker, creeping, and tuber-forming. Native plants were dominant (148 species), while alien plants included 108 species (42\%).

The use of herbicides drastically decreased the weed infestation of crops. It was shown the score abundance of weeds in arable plant communities was 1-2 points and the weed cover was 20-30\%. High plant cover was most often observed for Cirsium 
arvense (L.) Scop., Erodium cicutarium (L.) L'Hér., Convolvulus arvensis L., Sonchus arvensis L., Echinochloa crus-galli (L.) P. Beauv., Avena fatua L., Setaria viridis (L.) P. Beauv. etc.

The weed constancy class analysis showed: 15 species $(6 \%)$ had a constancy class of IV, 20 species (8\%) a class of III, and 36 species (14\%) a class of II. The vast majority of weeds (187 species or $72 \%$ ) had a constancy class of I, being found in a small number of examined arable plant communities.

The weed occurrence analysis revealed that most of the weeds (184 species or $71 \%$ ) had a moderate occurrence in the examined arable plant communities.

Twenty-two weed species $(9 \%)$ had a high occurrence. These species were not selective and were found in arable plant communities of all crops. These species included, for example, Cirsiumarvense, Erodium cicutarium, Galium spurium L., Fumaria officinalis L., Fallopia convolvulus (L.) A. Löve, Convolvulus arvensis, Viola arvensis Murray, Galeopsis bifida Boenn., G. speciose Mill., Avena fatua etc.

Fifty-two weed species (20\%) had low occurrence. Thirty-three weed species were unique to arable plant communities of spring crops. There were 28 native species (Agrostis stolonifera L., Arabis pendula L., Hypericum perforatum L., Persicaria minor (Huds.) Opiz, Solanum kitagawae Schonb.-Tem. etc.) and 5 alien species (Artemisia sieversiana Ehrh., Echinocystis lobate (Michx.) Torr. \& A. Gray, Echium vulgare L., Scleranthus annuus L. and Vicia villosa Roth). Thirteen weed species were unique to arable plant communities of perennial grasses: 6 alien species (Atriplex patula L., Cirsium vulgare (Savi) Ten., Lepidium densiflorum Schrad., Senecio vulgaris L. etc.) and 7 native species (Beckmannia syzigachne (Steud.) Fernald, Plantago lanceolate L., Verbascum nigrum L. etc.). There were 4 weed species in arable plant communities of row crops: 2 native species (Bidens radiate Thuill., Persicaria hydropiper (L.) Delarbre) and 2 alien species (Armoracia rusticana P. Gaertn., B. Mey. \& Scherb., Hyoscyamus niger L.). Two weed species were found only in arable plant communities of winter rye: the alien species Bromus secalinus L. and the native species Rumex confertus Willd.

All the weed species were divided into four groups.

Weeds most common in arable plant communities formed a group of highly active species with a high abundance. It was an extremely small group that included 17 species or $7 \%$ of the total weed species composition. Monocarpic grasses were most prevalent $(71 \%)$ in this group, while the other species were polycarpic grasses with intensive vegetative propagation (rhizome and root sucker plants).

The highly active weeds group contained 59\% alien species that were naturalized species in the natural flora: Erodium cicutarium, Thlaspi arvense L., Fumaria officinalis, Galeopsis bifida, G. speciosa, Convolvulus arvensis, Avena fatua, Viola arvensis, and Chenopodium album L. Native highly active weeds were mainly meadow species: Artemisia vulgaris L., Cirsium arvense, Taraxacum campylodes GE Haglund, Elymus repens (L.) Gould, Tripleurospermum inodorum (L.) Sch. Bip., Capsella bursa-pastoris (L.) Medikus, and Stellaria media (L.) Vill.

A group of moderately active weeds can also be considered as the most adapted to the arable plant communities and regarded as the active weeds of crops. This group comprised $9 \%$ of the total weed species composition. Monocarpic grasses dominated 
this group (61\%). Among the polycarpic grasses in this group were rhizome and rootsucker plants, tuber-forming species (Stachys palustris L.), and above-ground stolon-forming species (Potentilla anserine L.).

Native moderately active weeds accounted for $39 \%$ of the group. Meadow plants were most prevalent: Arctium tomentosum Mill., Bromus inermis Leyss., Linaria vulgaris Mill., Potentilla anserina, and Vicia cracca L. Alien moderately active weeds were represented by Cyanus segetum Hill, Echinochloa crus-galli, Sonchus arvensis, S. oleraceus (L.) L. etc.

Underactive and nonactive weeds comprised the majority of the weed species composition in the Central Urals (84\%). Underactive weeds (82 species or 32\%) were found in arable plant communities of many crops, but mainly in small numbers. The group of nonactive weeds was the most diverse and included about half of the weed species composition in the Central Urals (52\%).

In these groups the proportion of polycarpic grasses increased among life forms that did not have intensive vegetative propagation, such as cespitose plants.

Native species dominated the underactive and nonactive weed groups (60\% and $62 \%$ respectively). Moreover, their cenotic spectrum became more diverse. Forest species (Angelica sylvestris L., Aegopodium podagraria L. etc.), xerophytic community species (Dracocephalum thymiflorum L., Nonea rossica Steven), and petrophyte-steppe species (Cerastium arvense L.) appeared. In addition, there were species of waterlogged habitats such as meadow-bog (Ranunculus repens L., Lysimachia vulgaris L.), coastal water (Mentha arvensis L., Persicaria amphibia (L.) Delarbre, Rorippa palustris (L.) Besser), and erosiophilic species (Leonurus quinquelobatus Gilib., Polygonum aviculare L.).

The proportion of ruderal species was increased: Conium maculatum L., Bunias orientalis L., Erigeron canadensis L., Malva pusilla Sm., and Veronica persica Poir.

Table 2. Features of weed plants in the Central Urals (absolute number/proportion of the total, \%).

\begin{tabular}{|l|c|c|c|c|}
\hline \multicolumn{1}{|c|}{ Features } & Highly active & $\begin{array}{c}\text { Moderately } \\
\text { active }\end{array}$ & Underactive & Nonactive \\
\hline Total & 17 & 23 & 82 & 136 \\
\hline Number of native species & $7 / 41.2$ & $9 / 39.1$ & $49 / 59.8$ & $84 / 61.8$ \\
\hline Number of alien species & $10 / 58.8$ & $14 / 60.9$ & $33 / 40.2$ & $52 / 38.2$ \\
\hline Plant life-forms \\
\hline Monocarpic grasses & $12 / 70.6$ & $14 / 60.9$ & $36 / 43.9$ & $58 / 42.7$ \\
\hline Polycarpic grasses & $5 / 29.4$ & $8 / 34.8$ & $45 / 54.9$ & $75 / 55.2$ \\
\hline Trees & 0 & 0 & 0 & $1 / 0.7$ \\
\hline Semiarborescent plants & 0 & 0 & 0 & $1 / 0.7$ \\
\hline $\begin{array}{l}\text { Spore plants, rhizomatous } \\
\text { have grasses }\end{array}$ & 0 & $1 / 4.3$ & $1 / 1.2$ & $1 / 0.7$ \\
\hline
\end{tabular}


To mobilize collected data, we published the dataset for weed species composition and distribution in the Central Urals, through Global biodiversity information facility GBIF (Tretyakova et al. 2019). The occurrence dataset includes 2730 records of the authors' collections from 2016 to 2019 of vascular plants from the phylum Magnoliopsida, Liliopsida, and Equisetopsida. The dataset includes metadata about the natural conditions of the Central Urals and the methods of data collection. The authors plan to supplement the data with the herbariums of the Institute of Plant and Animal Ecology (SVER) and Ural Federal University (UFU), which will extend the observations.

GBIF dataset contributes to open biodiversity data for Russian territory. It provides new information about geographical distribution of weeds in crops of the Central Urals. We hope that it promotes the data accessibility and reuse for Russian and foreign researchers.

\section{Conclusion}

Most weeds in arable plant communities in the Central Urals are underactive ( 82 species or $32 \%$ ) and nonactive (136 species or 52\%). The groups of the most active (aggressive) weeds include 40 species $(16 \%)$. They are dominated by alien species which naturalized in the natural flora. The proportion of monocarpic grasses is higher than polycarpic grasses, mainly represented by rootsucker plants and rhizome species with intensive vegetative propagation.

The same patterns were noted in other region of Russia - Ryazan oblast (1 $300 \mathrm{~km}$ towards west from Sverdlovsk oblast): only 27 weed species (10\%) were highly and moderately active weeds. Most of them were annual plants. It should be noted that the composition of the most active weeds in arable land of Sverdlovsk and Ryazan oblasts was presented by almost the same set of species (Palkina 2015).

\section{Acknowledgments}

This work was supported in part by the Russian Foundation for Basic Research (projects 19-016-00135) and the Program for Improving the Competitiveness of the Ural Federal University (the decree no. 211 of the Government of the Russian Federation, contract no. 02.A03.21.0006).

\section{References}

Baranova OG (2002) Mestnaya flora: analiz, konspekt, okhrana: Uchebnoye posobiye [Local flora: analysis, compendium, conservation: workbook]. Udmurt State University, Izhevsk, 199 pp. [in Russian].

Galon L, Concenço G, Perin GF, da Silva AF, Forte CT, de Adelio David F, Radüz LL, Radunz AL, Andres A, Tironi SP, Concenço SE (2015) Comparison of experimental methods to assess the competitive ability of weed species. American Journal of Plant Sciences 6: 2185-2196. http://dx.doi.org/10.4236/ ajps.2015.613221.

Gbèhounou G (2013). Guidance on weed issues and assessment of noxious weeds in a context of harmonized legislation for production of certified seed. FAO Plant Production \& Protection Division, Rome, pp. 1-39. http://www.fao.org/3/ai3493e.pdf. 
Holzner W (1982) Concepts, categories and characteristics of weeds. In: Holzner W, Numata M (Eds) Biology and ecology of weeds. Geobotany, vol. 2. Springer, Dordrecht, pp. 3-20. https://doi.org/10.1007/978-94-017-0916-3_1.

Khasanova GR, Yamalov SM, Korchev VV (2014) Floristicheskii sostav segetal'nykh soobshchestv respubliki Bashkortostan [The floristic composition of the Southern Urals segetal communities]. Vestnik Bashkirskogo gosudarstvennogo agrarnogo universiteta [Vestnik of the Bashkir State Agrarian University] 2: 38-41 [in Russian].

Khasanova GR, Golovanov YM, Yamalov SM (2016) Dinamika taksonomicheskogo spectra segetal'noy flory Yuzhnogo Urala [Dynamics of the taxanomic spectre of segetal flora of South Urals]. Izvestiya Orenburgskogo gosudarstvennogo agrarnogo universiteta [News of the Orenburg State Agrarian University] 1: 133135 [in Russian].

Kondratkov PV, Tretyakova AS (2019a) Konspekt segetal'noi flory Sverdlovskoi oblasti [A checklist of the segetal flora of the Sverdlovsk region]. Vestnik Permskogo universiteta. Biologija [Bulletin of Perm University. Biology] 1: 26-41 [in Russian]. https://doi.org/10.17072/1994-9952-2019-1-26-41.

Kondratkov PV, Tretyakova AS (2019b) Segetal'naya flora Sverdlovskoi oblasti [Segetal flora in Sverdlovsk region]. Vestnik Orenburgskogo gosudarstvennogo pedagogicheskogo universiteta. Jelektronnyj nauchnyj zhurnal [Vestnik of Orenburg State Pedagogical University. Electronic Scientific Journal] 2: 26-37 [in Russian]. https://doi.org/10.32516/2303-9922.2019.31.3.

Maltsev AI (1962) Sornaya rastitel'nost' SSSR i mery bor'by s ney [Weed vegetation of the USSR and management action]. Selkhozizdat Printing House, Leningrad, Moscow, 272 pp. [in Russian].

Markov MV (1972) Agrofitotsenologiya [Agrophytocenology]. Kazan State University Printing House, Kazan, 270 pp. [in Russian].

Mirkin BM, Abramova LM, Ishbirdin AR, Rudakov KM, Khaziyev FKh (1985) Segetal'nyye soobshchestva Bashkirii [Segetal communities of Bashkiria]. Institute of Biology, Bashkir Branch of the Academy of Sciences of the USSR, Ufa, 155 pp. [in Russian].

Palkina TA (2015) Struktura segetal'noi flory Ryazanskoi oblasti [The segetal flora structure in Ryazan oblast]. Vestnik Ryazanskogo gosudarstvennogo agrotekhnologicheskogo universiteta imeni P.A. Kostycheva [Bulletin of the Ryazan State Agrotechnological University named after P.A. Kostychev] 3: 26-32 [in Russian].

Rana SS, Rana MC (2016) Principles and Practices of Weed Management. Department of Agronomy, College of Agriculture, CSK Himachal Pradesh Krishi Vishvavidyalaya, Palampur 138.

Scherbakov AV, Maiorov SR (2006) Inventarizatsiya flory i osnovy gerbarnogo dela: metodicheskiye rekomendatsii [Inventory of flora and the basics of herbarium treatment: guidelines]. KMK, Moscow, 50 pp. [in Russian]. 
Terekhina TA (2000) Antropogennyye fitosistemy [Anthropogenic phytosystems]. Altai State University, Barnaul, 250 pp. [in Russian].

Tretyakova AS, Kondratkov PV (2018a) Geographical Patterns of Weed Diversity in the Central Urals. In: Tretyakova AS, Veselkin DV (Eds) The fourth International Scientific Conference on Ecology and Geography of Plants and Plant Communities (Russia), April 2018. KnE Life Sciences, Dubai, 219-224. https://doi.org/10.18502/kls.v4i7.3242.

Tretyakova AS, Kondratkov PV (2018b) Izmeneniya vidovogo sostava segetal'nykh rastenii Sverdlovskoi oblasti [Dynamics of the segetal species composition in the Sverdlovsk region]. Botanicheskii Zhurnal 103 (12): 1607-1622 [in Russian]. https://doi.org/10.1134/S0006813618120086.

Tretyakova AS, Kondratkov PV, Grudanov NY (2019) Weed species of the Central Urals (Sverdlovsk region). Occurrence dataset. Federal State Autonomous Educational Institution of Higher Education «Ural Federal University named after the first President of Russia B.N. Yeltsin». https://doi.org/10.15468/6zaucq [Accessed on 10.06.2020]

Tretyakova AS, Baranova OG, Luneva NN, Terekhina TA, Yamalov SM, Lebedeva MV, Khasanova GR, Grudanov NYu (2020) Segetal'naya flora nekotorykh regionov Rossii: kharakteristika taksonomicheskoi struktury [Segetal flora of some regions of Russia: characteristics of the taxonomic structure]. Trudy po prikladnoj botanike, genetike i selekcii [Proceedings on Applied Botany, Genetics and Breeding] 181 (2): 123-133 [in Russian]. https://doi.org/10.30901/2227-88342020-2-123-133 .

Tuganayev VV, Lekontseva LR, Puzyrev AN (2015) Botanicheskiy obzor i istoriya agroekosistem Vyatsko-Kamskogo Predural'ya [Botanical review and history of agroecosystems of the Vyatka-Kama Cis-Urals]. Institute of Computer Research, Moscow, Izhevsk, 192 pp. [in Russian].

Ulyanova TN (1985) Vidovoy sostav osnovnykh sorno-polevykh rasteniy flory Sovetskogo Dal'nego Vostoka [The species composition of the main weed-field plants of the flora of the Soviet Far East]. Botanicheskii Zhurnal 70 (4): 482-490 [in Russian].

Ulyanova TN (2005) Sornyye rasteniya vo flore Rossii i sopredel'nykh gosudarstv [Weeds in the flora of Russia and neighboring states]. Altai State University, South Siberian Botanical Garden, Barnaul, 295 pp. [in Russian]. 